Meta

Journal des traducteurs

Translators' Journal

\title{
Ideology, Orality and Colonization: The Translation of José de la Cuadra's Los Sangurimas (1934)
}

\section{Kenneth Wishnia}

Volume 40, numéro 1, mars 1995

URI : https://id.erudit.org/iderudit/004613ar

DOI : https://doi.org/10.7202/004613ar

Aller au sommaire du numéro

\section{Éditeur(s)}

Les Presses de l'Université de Montréal

ISSN

0026-0452 (imprimé)

1492-1421 (numérique)

Découvrir la revue

\section{Citer cet article}

Wishnia, K. (1995). Ideology, Orality and Colonization: The Translation of José de la Cuadra's Los Sangurimas (1934). Meta, 40(1), 24-30.

https://doi.org/10.7202/004613ar

\section{Résumé de l'article}

La majorité des théories de la traduction se jouent entre deux extrêmes : la fidélité excessive qui tente de rendre le traducteur invisible pour le lecteur, et la récréation où le traducteur refait le texte de départ selon sa propre vision. Quoiqu'en général les théoriciens de la traduction se situent quelque part au centre, les praticiens se retrouvent souvent près d'un de ces extrêmes. Quelles libertés un traducteur peut-il prendre face à un texte étranger difficile? À quel moment la liberlé devient-elle de l'appropriation? Dans les deux premiers tiers de cet article, l'auteur discute des principales questions d'intérêt pour la théorie de la traduction. Le dernier tiers reprend ces questions en contexte, c'est-à-dire en examinant la traduction d'un des principaux texte de l'Équatorien José de la Cuadra: Los Sungurimas . 


\title{
IDEOLOGY, ORALITY AND \\ COLONIZATION: THE TRANSLATION OF JOSÉ DE LA CUADRA'S LOS SANGURIMAS (1934)
}

\author{
KIENNITH WISHINIA

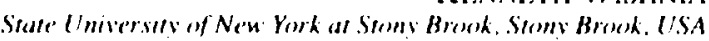

\begin{abstract}
Résumé
La majorité des théories de la traduction se jousent entre de'ux extremes : la fidélité

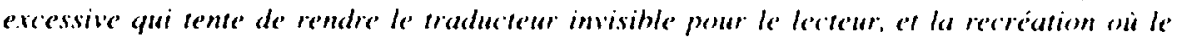

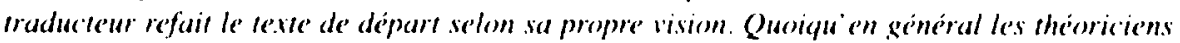

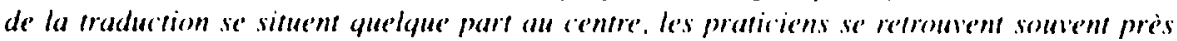

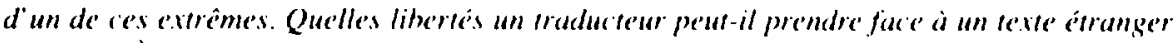
difficile.' A quel moment la liberté devic'nt-elle de lappropriation?" Dans les deux premiers

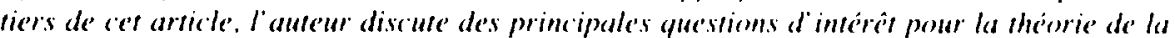

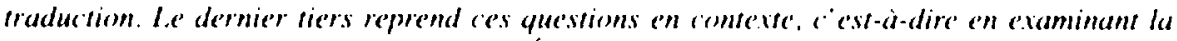

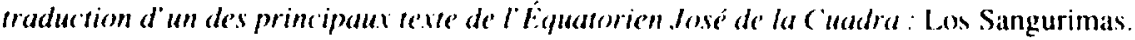

Most theoretical approaches to translation operate between two extremes: on the one hand, an excessive fidelity that insists on the invisibility of the translator in conveying " 100 percent of the meaning" of the original: on the other, the valorization of the translator as re-creator, freely reshaping a text according to his or her vision. Though translation theorists generally call for moderation between the 1 wo, many practices lie much closer to the extremes. What liberties, then, can a translator take with a difficult foreign text? At what point do liberrie's become appropriation? The first two-thirds of this paper discusses current issues in translation theory: the final third re-discusses them in the context of the translation of one of the pivotal works of Ecuadorean Modernism. José de la Cuadra's Los Sangurimas (1934).

In the case of the " $1(X)$ percent of the meaning" school, one must ask: Whose meaning? Are we mind readers, that we should know the authors full intent? Are we so naive as to believe still that the author's intent produces 100 percent of the meaning in a text'? Also, what of deliberate ambiguity? And what of tone'? (ct. Bly 1973; for a detailed critique of excessive fidelity, see D. S. Carne-Ross on Richmond Lattimore's Iranslations of Homer). I am not sure that tone can be translated. Mildred Larson's definition seems like a good dialogic compromise:

Anything which can be said in one language can be said in another. It is possible to translate. The goal of the translator is to keep the meaning constant. Wherever necessury, the receptor language form should be changed in order that the source language meaning not be distorted (Larson 1984: 11: emphasis in original).

And yet, the question remains, whose responsibility is it to identify the meaning inherent in a given text? Barbara Johnson asks what meaning Plato intended by the word Pharmakon, since the word "can mean both 'poison" and 'remedy' and thus makes

Mera, XL. 1, 1995 
problematic any statement in which it occurs" (Johnson 1985: 145). Peter Newmark notes that "no sign...has self-contained meaning." and points out that the (presumably unproblematic) English word baw'dy is defined six different ways by six contemporary English language dictionaries (Newmark 1988: 5, 27). If Walter Benjamin's definition of inferior translation is "the inaccurate transmission of an inessential content" (Benjamin 1969: 70), then we must assume that a good translation is the accurate translation of the essential content, or meaning, which brings me back to my initial question: Whose meaning?

In Some Versions of Homer, Borges writes (through translator Suzanne Jill Levine)

The main cause [of deviations among translations] is the impossibility of knowing what belonged to the poet and what belonged to the language $|\ldots|$ When we read in the seventeenth-century playwright Agustín Moreto [...] the phrase "Pues en casa tan compuestas / $Q$ Qué hacen todo el santo dia'?" 'What do these prim ladies do at home the whole damn day?' we know that the day's unholiness belongs to the language and not to the writer. Where Homer's accents lie, however, we can never know (Borges 1992: 1136-1137).

Susan Bassnett-McGuire (1988: 14-15) provides a way out of this dilemma: "There is ordinarily no full equivalence through translation |... | Only creative transposition is possible". The question is, How far can one go? At what point does creative transposition become betrayal? Mildred Larson makes a strong case for certain episodes of meaninghased translation:

[T] The word cross refers to the wooden cross used for crucifixion during the time of the Roman Empire. However, for Christians, it has a symbolic meaning beyond the basic meaning. Symbolically, it means death and suffering, and even beyond that, it stands for Christianity [...] Notice, for example, that in the following translations of Ephesians 2:16, the word cross is retained even though an addition has been made in order to carry the correct meaning:

Source text: $[\ldots]$ might reconcile us both to God in one body through the cross thereby bringing hostility to and end $[\ldots]$

Receptor language 1: by his death on the cross Christ destroyed the enmity: by means of the cross he united both races into one body and brought them back to God.

Receptor language 2: he died on the cross to put an end to the hatred and bring us both back to God as one people (Larson 1984: 181: all emphases in original).

Larson's concept seems useful, and I have used it half a dozen times or so in my translation of Los Sangurimas. William Arrowsmith, in the Introduction to his translation of The Birds, makes a good case for occasionally going even further.

Any translation worth the name necessarily involves an interpretation [...] This translation is meant to provide a faithful, but not literal, version of The Birds. Literalness in any case is out of the question: a literal Aristophanes would be both unreadable and unplayable, and therefore unfaithful. But fidelity is clearly a matter of degree and relation: how faithful and faithful to whar? (Arrowsmith 1970: 7, 12)

What, indeed'? In the case of Aristophanes it is the distance of the source culture from the target culture that justifies such tactics. What, then, of the (in)famous Pound/Fenollosa translation, The Classic Noh Theatre of Japan? Surely the source culture is just as foreign as that of ancient Greece for the modern Anglo reader? Yet a more contemporary translator of "Nö" plays, Donald Keene, makes veiled reference to unreliable fifty-year-old translations (Keene 1970: $x$ ). The greatest problem with Pound's "Noh" is not the cultural distance, but his own imperialistic attitude towards the source culture: Fenollosa, says Pound. "had unearthed treasure that no Japanese had heard of," and had, according to the opening biographical sketch, "singlehandedly pursuad|ed] the Japanese to preserve their 
cultural heritage" (1959: 3, front matter). By contrast. Keene (1970: xii) writes that the "Nö" theatre "has withstood change for 500 years and is now more popular than ever". So whom do we believe?

Cultural imperialism in translation is a major issue. It may begin innocently with "culturally re-contextualized semantic transfer" (Doyle 1989: 41), but even George Steiner, who early on notes that, ideally, "The arrows of meaning, of cultural, psychological benefaction. move both ways" (1975: 302), posits a kind a translation that can be seen as appropriation:

The translator invades, extracts, and brings home $|\ldots|$ Master translations domesticate the foreign original by exchanging an obtrusive geographical-linguistic distance for a much subtler, internalized distance in time (1975: 298, 347)

and valorizes Pound's approach by crediting him with the ability "to enter into alien guise, to assume the mask and gait of other cultures" (1975: 3.59), a tactic that many contemporaries would consider offensive and impossible. This is not a new issue. BassnetlMcGuire quotes Edward Fitzgerald, writing in 1851 .

It is an amusement to me to take what liberties I like with these Persians, who, (as I think) are not Poets enough to frighten one from such excursion, and who really do want a little Art to shape them (1988: 3: see also Lefevere 1992: 119)

and Benjamin (1969: 80) quotes Pannwitz:

Our translations, even the best ones, proceed from a wrong premise. They want to turn Hindi, Greek. English into German instead of turning German into Hindi, Greek, English. Our translators have a far greater reverence for the usage of the ir own language than for the spirit of foreign works.

Lawrence Venuti argues for a dialogic compromise. that a good translation of a distant source culture text should strive to keep the strange:

resistant strategies can help to preserve the linguistic and cultural difference of the foreign text by producing translations which are strange and estranging, which mark the limits of dominant values in the target-language culture and hinder those values from enacting an imperialistic domestication of a cultural other (1992:13).

Such imperialistic translation can also be seen as part of the process of canonization, the domestication and incorporation into a dominant culture of potentially dissident voices. Conversely, however, translation can also be seen as liberating. Lynn Tuttle (1979: 14) remarks that "nations are prisoners of the languages they speak. Within each language the divisions are reproduced: historical periods, social classes, generations". Translation is a way out of this prison. (Basil Davidson (1974: 241) credits the translation of the Bible into Yoruba with considerable importance "in the formation of anti-colonial trends of thought"). Newmark puts this issue into tangible economic numbers:

Some "international" writers (in the age of "international" culture and world-literature) immediately sell more widely in translation than in the original (1988: 3)

And Samia Mehrez (1992: 121, 124) explores the issue of "Third World postcolonial plurilingual writers, writing in the language of the ex-colonizer." whose conflation of two worlds causes "master language" readers to "lose their way in their own language just as they would lose their way in the meandering alleys of the cashat".

Thus I return to my opening questions: What liberties, then, can a translator take with a difficult foreign text? At what point do lihertie's become appropriation? Barbara 
Stoler Miller (1984: 24-25) writes that the plays of Kälidäsa were written for a multilingual audience in Sanskrit and a variety of Prakrits, which are impossible to reproduce in English translation, since no distinctions of dialect adequately capture the Prakrits". Should she have tried harder? Or. conversely. would the attempt to reproduce these dialects in English be a falsehood? I am inclined to support her and suggest the latter. With apologies to William Arrowsmith, the "Brooklyn" Herakles in The Birds is a failure (e.g.. "Dat's a shame," "Youse is so right." "She's for the boids," Arrowsmith 1970: 124-30: cf. Lefevere who notes that "The two perennial candidates for this kind of sociolect switch are Scots and something perhaps best defined as Generic Southern American " [Lefevere. 66]). It marks the text inappropriately with multiple meanings foreign to the text.

In the text I am translating. Los Sangurimas, the dialogue represents the oral campesinos of Ecuador's tropical coast during the 1930s and earlier. All of the characters. high and low, speak a similar, non-standard Spanish. I have chosen to suggest this through occasional use of non-standard English, but did not attempt to re-create their speech in English using. say. New Orleans dockyard slang. Why'? Because that would be nearly as foreign to the English-speaking audience as the Spanish original.

Suzanne Jill Levine (1991: 123-134) writes of substitutions of Argentine popular culture rlichés for American ones in her translation of Manuel Puig's Boquitas pintadas; these substitutions have failed to convince some, constituting an example, perhaps, of going too far. However, few translators have the luxury of collaborating with living authors, so Levine's tactics, successful or not, may only serve in those limited cases wherein authors essentially collaborate on a re-creation of their work in translation (cf. James Joyce with the Italian translation of Finnegan's Wake. Borges and the English translation of The Book of Imaginary Beings, and Günther Grass's comment that his translators, with whom he regularly collaborates. are his "very best readers" (Vinocur 1980: 2)).

My undergraduate advisor, the late George H. Bass, director of the Afro-American Studies Department at Brown University, used the following example of how, superficially, meaning can be constant through a variety of forms. One can say:

I've had enough of you motherfuckers fucking with me - you can all kiss my Black ass!

Or one can say:

Gentlemen, ladies. I thank you for your time; if, as I take my leave of you, you would please imagine that a sprig of mistletoe has been affixed to my coattail, and honor it.

But altering the form does change the meaning: These two sentences do not mean the same thing.

Irene B. Hodgson writes of the ultimate extreme, wherein translators and publishers have decided to leave out entire passages from such major works as La muerte de Artemio Cruz (Fuentes) and ¿Quien mato a Palomino Molero?' (Vargas Llosa) because of economic considerations ("the translation [should] have fewer pages than the original"), bad translation decisions ("the relative impossibility of translating certain concepts"), which is to say, bad literary analysis decisions, that "certain parts of the work $|\ldots|$ are not essential" (Hodgson: 310), and the following utterly galling reason (in the case of :Quien mató a Palomino Molero?):

to make the novel more attractive to an American public by making it follow more closely the established conventions for the detective novel (Hodgson: 312).

If that isn't an example of imperialistic appropriation of a Third World text, I don't know what is. Hodgson's thesis is that these tactics result in the following: 
1) the possibilities of the novel may be limited or eliminated by the omission - that is, possible interpretations or levels of interpretation may be absent. And therefore, (2), the experience of the reader who reads only the translation may be significantly different than that of a reader of the original text (Hodgson: 310).

Clearly this is an unacceptable situation for any literary scholar.

I now turn to discussion of my translation of Los Sangurimas, into which I have carried all this theoretical baggage. I have discussed the historical and literary content of this work elsewhere, and will not dwell excessively on it here (see Wishnia 1993). Suffice it to say that José de la Cuadra was one of the principal Ecuadorean modernists of the 1930 s, one of whose primary projects was the replacement of the high lexical social register put in the mouths of illiterates by such 19th-century authors as Juan Leon Mera (e.g.. Cumanda, 1879) with a naturalism that included reproducing local dialect and describing scenes of violence, ignorance, incest, etc. (Cueva 1981: 41: 1988: 638, 640-641). This poses unique problems for the translator. I'm not sure 1 can translate the tome of Los Sangurimas, which is primarily the speech of non-literate squatters and peasants on Ecuador's tropical coast in the early 1930s. With what equivalent? I have chosen a relattively neutral, rarely non-standard English. which I feel is somehow less-of-a-lie.

Generally, with Spanish to English translation, the first matter to be engaged is likely to be the Latinate roots of Spanish that often have cognates in English, which are therefore the first words that might excur to the translator. But these words, which are common in Spanish, sound misplaced in English, where Latinate words belong to a higher register than Anglo-Saxon. Suzanne Jill Levine (1991: 2-3) discusses

the temptation to choose cognates. Latinate words whose effect in English is often archaic, or even vague, such as amiable, whereas the Spanish counterpart ameshle is a common. vivid word $[\ldots \mid$ The Spanish language tolerates, even seeks polyvalence, while modern English demands straight-forward clarity.

How do we avoid what Bly calls "translatorese"'? (1984: 77; there is also Gregory Rabassa's example (p. 43) of the opposite register, how the Spanish cono is much more vulgar in English and therefore an inappropriate choice in the context he is discussing). In the case of Los Sangurimas I have translated such words as interlocutor, compadre and disimular. not as interlocutor. compatriot and dissemble but as other speake' friend and to hide it. Even documento, for which dorumem seems a perfectly serviceable word, comes from the mouth of a peasant, so I have rendered it as both pact (to sound more common) and as document, because Ecuador (like many countries), is so strangled by an inept hureaucracy that it is perfectly appropriate for non-literates to use what might sound like the high term, documem, because they would in fact be hearing it all the time.

This brings me to the issue of orality. This novel has so much dialogue between largely unidentified speakers that Humberto Robles has stated: "/M/ás que leeer la narración, se la escucha" ("Rather than reading the narrative, one listens to it." Robles 1979: 89). These speakers (typically non-literate) tell stories that raise the title characters to the level of myth. a common characteristic of orality (Goody \& Watt 1972: 318. 352). That the patriarch. Nicasio Sangurima. repeatedly negates the anonymous peasants versions of these myths with his own true versions does not negate the orality of the work. but redoubles it.

For example, these narrative variants differ in their approach to time, another characteristic of orality: according to one anonymous speaker. Nicasio Sangurima was an adult "hace años... a los menos cien" "at least a hundred... years ago", putting his age at least at 120, while one of Nicasio Sangurima's narratives places his birth no earlier than 1860 (although significantly no year is given), which means. for a 1934 novel, that he 
could not be older than 74; finally, the narrator tells us that Nicasio's eldest son is in his seventies, thereby supplying a compromise age roughly in the nineties for the old patriarch (de la Cuadra 1986: 19, 10-11, 29; cf. Walter Ong 1982: 76, on time). And in spite of the apparent domination of print, having a good "ear for dialogue" is still praise for an author

Print fixes narrative in space as well as time (Ong 1982: 133). In de la Cuadra's novel, "las fábulas terribles y las más terribles verdades" "the terrible fables and more terrible truths" (de la Cuadra 1986: 33) that the montuvio people tell about the Sangurimas have no effect on the patriarch's power, it is only when one of their crimes is reported in the Guayaquil newspapers that the municipal authorities close in and destroy it (see Wishnia 1993).

All right: but what, you may ask, is a montuvio? A montuvio is a concept that I have rendered three different ways. The first time, in an example of meaning-based translation. I chose a detailed explanation, "the montuvio people of the coastal lowlands." The next three or four times, I used "montuvio people," and subsequently, throughout the translation, I used just montuvio (or the plural montuvios).

Allow me to list a few other examples of where I have applied meaning-based translation. On page 9 of the original, Nicasio Sangurima boasts, "Yo soy, de madera incorruptible. Guachapeli, a lo menos." "I'm made of the toughest wood," seems obvious for the first sentence, but what on earth is Guachapeli? It turns out to be a very hard wood, related to the English acacia, used for shipbuilding. Clearly acacia would have not much more meaning for the average English reader than would Guachapelf. Since Los Sangurimas takes place among a wetland community, born into shipping the way gauchos might be said to be born in the saddle, and the novel is filled with marine metaphors, I opted for a supplementary explanatory phrase: "The toughest wood, that's me. Ironwood, at least. Like the shipbuilders use."

Of course, when a South American uses invierno ('winter', de la Cuadra 1986: 30) to refer to the hottest time of the year, it is easy to justify summer as a translation, but what of "Vega en la orilla. no más. Pa dentro, barranco alto sodito. Terreno pa invernar" (de la Cuadra 1986: 18)? What is one to do with the final phrase, which might be rendered into English as "Land for getting through the winter"? Leaving aside the regional pronunciation of pa for para, which I generally have attempted to render with displaced, slightly non-standard English (cf. Levine's example 1991: 70), not all South Americans consider "winter" to be, as it is on Ecuador's coast, the wettest as well as the hottest season. I therefore opted for "Low and swampy only down by the river. But inside, high ravines all over. Way "bove the flood plain."

Finally, there are the extreme cases of local slang and idioms. My wife, a native of Ecuador, was able to supply translations of some terms not in any major Spanish-English dictionary that are still current in Ecuadorean speech, but there are several terms that require discussion with informed native speakers who are familiar with the 1930s-era slang of Ecuador's coast. De la Cuadra describes a dead person as having la cara josca (14), which is an attempt to reproduce the local pronunciation of the initial $t$ - as the guttural $h$ - (the word is tosca, i.e., stiff with rigor mortis) and la ley de fuga is invoked against los comevaca (15), which turns out to be the shooting of cattle rustlers, and Nicasio Sangurima calls himself a come hollo-maduro (25; literally, a "ripe-plantain-balleater"). Although the narrative context clearly refers to the destructiveness of greed overeating may kill you - (a bollo is made of mashed plantain and other ingredients rolled into a ball) I was advised, in order to learn the specific regional and temporal meaning of this term, to travel to a single village outside Guayaquil, where this expression may still be current. If my experience dealing with this culture is anything to go by, 
I may be supplied with multiple, contradictory meanings. De la Cuadra may have heard some of the other terms in Los Sangurimas once only and included them, or even invented some of them. But if I can establish the indeterminacy of meaning in the original with any authority, then my substitutions will be justified.

\section{REFERENCES}

ARROWSMITH. William (1970): Trans. Introduction 10 The Birds (Aristophanes). New York. Mentor Books.

BASSNETT-MCG(JIRE. Susan (1988): Trunslation Studies, London, Routledge, I980.

BENJAMIN. Walter (1969): "The Task of the Translator". Illominations, Hannah Arendt. Trans. New York. Schocken.

BORGES, Jorge Luis (1992): "Some Versions of Homer". Trans. Suranne Jill Levine, PMIA 107.5 (O)tober. 1992). pp. 1134-1138.

BLY, Robert (1984): "The Fight Stages of Translation", W. Frawley (Fd.), Thanslation: Literorv. Linguissic d Philosophical Perspectives. Newark. University of Delaware.

CARNE-ROSS, D. S. (1968): "A Mistaken Ambition of Exactness", Deles, 2, pp. 171-195.

CUEVA. Agustin (1981): "I:I método materialista historico aplicados a la perionlización de la hestoria de la literatura Fcuatoriana: Algunas consideraciones teoricas", ("asa de las Americas, 22, pp. $31-47$.

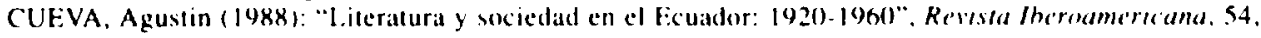
pp. 629-647.

DAVIDSON, Basil (1974): Africa in Misfory. New York. Collier.

DE LA CUADRA, Jose (1986): Los Sangurimas, Quito, El Conejo.

DOYLE. Michatel S. (1989): "Contemporary Spanish and Spanish American Fiction in English: Tropes of Fidelity in the Translation of Titles". Translatum Kese'w, 30/31, pp. $41-46$.

GOODY, J. and I. WATT (1972): "The Consequences of Literacy", Pier Paolo (iiglioli (Ed.), lamguage and Sorial Comleli. New York. Vikıng Penguin.

HODGSON, Irene B. (s.d.): "Effects of Translation on Interpretation and Reader Response in Some Recent Latin American Novels". William Lum and Julio Roglrigue/-luis (IEds.). Translating Lamm Amernca: Culture as Te' B. Binghamton, SUNY Binghamton Center for Rescarch in Translation.

JOHNSON, Barbara (1985): "Taking Fidelity Philosophically", Joueph F. (iraham (Fid.). I) fferemee In Translation, lihaca, (omcll UP.

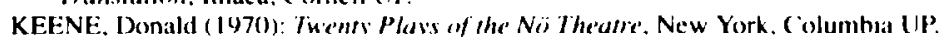

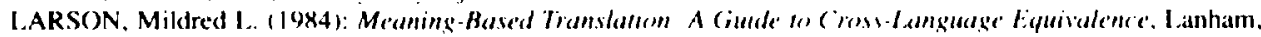
MD. UP of America.

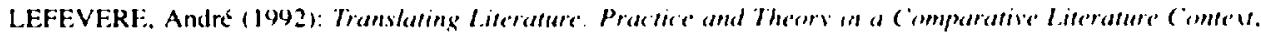
New York. MLA.

LEVINE, Suzanne Jill (1991): The Subversive Scrthe: Translating Latin Amerncun Fition. St. Paul. Greywolt Press.

MEHREZ, Samia ( 1992 ): "Translation and the Postcolonial Experience: 'The Francophone North African Text".

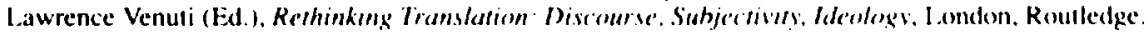

NEWMARK, Peter (1988): Approaches to Tianslation, New Yorh. Prentice Hall.

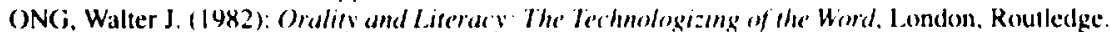

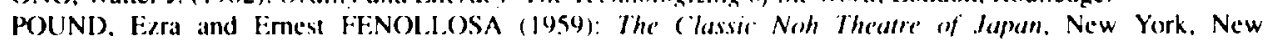
Directions.

RABASSA. Ciregory (s.d.): "Words Cannot Express... The Translatıon of (ultures". Willaam l.uis and Julio Rodrigue, Luis (Eds.). Translasing Lasin Ameriea. Culture as Tev. Binghamton. SUNY Binghamton (enter for Research in Translation.

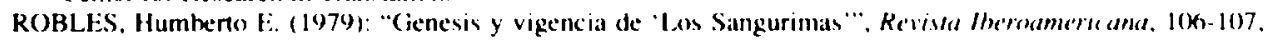
Pp. $8.5-91$

STEINER, (j. (1975): Affer Babel, london, Oxford (JP.

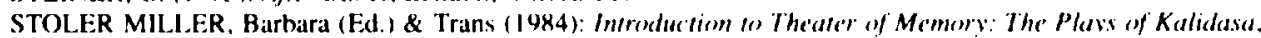
New York, Columbia (IP.

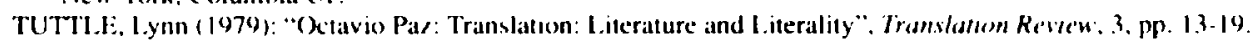

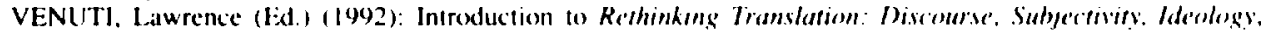
london. Routledge:

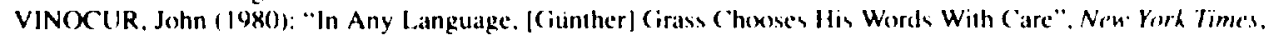
Jan. 26 ' 80 . p. A2

WISHNIA. Kenneth (199.3): "Sterile Fertility/Fertile Sierility: Identity. Negation and Narrative in Jose de la

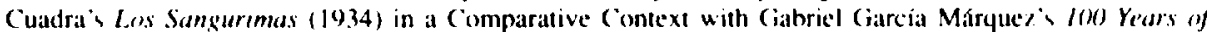
Solinde (1967)". Paper de livered at the Twentieth Century literature Conference, Iniversity of l.ouisville. Feb. 25-27, 1903 